\title{
Erratum: BatTool: an R package with GUI for assessing the effect of white-nose syndrome and other take events on Myotis spp. of bats
}

Richard A Erickson ${ }^{1 *}$, Wayne E Thogmartin ${ }^{1}$ and Jennifer A Szymanski ${ }^{2}$

\section{Erratum}

After publication of this work [1], we were notified that part of the graphical user interface failed to function correctly. Specifically, the white-nose syndrome take scenarios did not load correctly. The command line aspects of the package were unaffected. This error has been corrected and new code attached.

\section{Additional file}

Additional file 1: This file contains the needed files to run the model as well as the package in both tar.gz format for Linux and OS X as well as the .zip _le for Windows.

\section{Competing interests}

The authors declare that they have no competing interests. Any use of trade, product, or firm names are for descriptive purposes only and do not imply endorsement by the U.S. Government. The views expressed in this article are the authors' own and do not necessarily represent the views of the U.S. Fish and Wildlife Service.

\section{Acknowledgments}

R. Niver caught the error in the code and we thank her for this feedback.

\section{Author details}

'Upper Midwest Environmental, Science Center, U.S. Geological, Survey, 2630 Fanta Reed Road, 54603 La Crosse, WI, USA. ${ }^{2}$ Division of Endangered Species, U.S. Fish and Wildlife Service, 555 Lester Avenue, 54650 Onalaksa, WI, USA.

Received: 27 November 2014 Accepted: 27 November 2014

Published online: 20 December 2014

\footnotetext{
* Correspondence: rerickson@usgs.gov

'Upper Midwest Environmental, Science Center, U.S. Geological, Survey, 2630 Fanta Reed Road, 54603 La Crosse, WI, USA

Full list of author information is available at the end of the article
}

\section{Reference}

1. Erickson RA, Thogmartin WE, Szymanski JA: BatTool: an R package with GUI for assessing the effect of White-nose Syndrome and other take events on Myotis spp. of bats. Source Code for Biology and Medicine 2014, 9:9.

\section{doi:10.1186/s13029-014-0028-9}

Cite this article as: Erickson et al:: Erratum: BatTool: an R package with GUI for assessing the effect of white-nose syndrome and other take events on Myotis spp. of bats. Source Code for Biology and Medicine 2014 9:28.

\section{Submit your next manuscript to BioMed Central and take full advantage of:}

- Convenient online submission

- Thorough peer review

- No space constraints or color figure charges

- Immediate publication on acceptance

- Inclusion in PubMed, CAS, Scopus and Google Scholar

- Research which is freely available for redistribution

Submit your manuscript at www.biomedcentral.com/submit 